\title{
Cobetia crustatorum sp. nov., a novel slightly halophilic bacterium isolated from traditional fermented seafood in Korea
}

\author{
Min-Soo Kim, Seong Woon Roh and Jin-Woo Bae
}

Correspondence

Jin-Woo Bae

baejw@khu.ac.kr

\author{
Department of Life and Nanopharmaceutical Sciences and Department of Biology, Kyung Hee \\ University, Seoul 130-701, Republic of Korea
}

The genus Cobetia comprises aerobic, Gram-stain-negative, slightly halophilic, rod-shaped micro-organisms. It is distinct from the genus Halomonas (Arahal et al., 2002a) and is one of 11 genera of the family Halomonadaceae. Historically, Cobetia marina was first described as Arthrobacter marinus by Cobet et al. (1970), but was later identified as Pseudomonas marina (Baumann et al., 1972). Approximately 10 years later, Cobetia marina was reclassified once again within the genus Deleya (Baumann et al., 1983) and then transferred to the genus Halomonas when the genera Deleya, Halomonas and Halovibrio, and Paracoccus halodenitrificans were unified by Dobson \& Franzmann (1996). After that, the number of the Halomonas species increased following studies of micro-organisms from different saline environments. As a result, the genus Halomonas contained species that were, in some cases, too different to justify their placement within the genus and the genus became heterogeneous (Arahal et al., 2002a; Romanenko et al., 2002). Delineation of the species in this genus was performed based on $16 \mathrm{~S}$ and $23 \mathrm{~S}$ rRNA sequence similarities (Arahal et al., 2002a, b). The sequence of Halomonas marina could be distinguished clearly from those of Halomonas and Chromohalobacter species based on $16 \mathrm{~S}$ and $23 \mathrm{~S}$ rRNA analyses and additional phenotypic evidence supported the inclusion of Halomonas marina in the novel genus Cobetia (Arahal et al., 2002a) as Cobetia marina. In a

Abbreviation: $\mathrm{PHB}$, poly- $\beta$-hydroxybutyric acid.

The GenBank/EMBL/DDBJ accession number for the $16 \mathrm{~S}$ rRNA gene sequence of strain $\mathrm{JO}^{\top}$ is EU909460. recent study of the microbial diversity of Korean traditional fermented seafood, a Cobetia-like strain, $\mathrm{JO}^{\mathrm{T}}{ }^{\mathrm{T}}$, was isolated.

Jeotgal, a traditional Korean fermented seafood, tastes salty with a slightly sour flavour. There are about 150 types of jeotgal, which has been consumed by Koreans since $683 \mathrm{AD}$ according to ancient records (Suh \& Yoon, 1987). A strain, designated strain $\mathrm{JO}^{\mathrm{T}}$, was isolated from a traditional fermented seafood in Korea called 'Jogae jeotgal'. It is generally made from the meat of thin-shelled surf clams, large clams and plenty of salt. Strain $\mathrm{JO}^{\mathrm{T}}$ was isolated on marine agar (MA; BBL) containing $7.5 \%$ salts. In this study, it is proposed that, based on molecular biological analyses and biochemical and phenotypic characteristics, strain $\mathrm{JO}^{\mathrm{T}}$ represents a novel species belonging to the genus Cobetia.

The isolate was transferred 2 or 3 times onto MA containing $7.5 \%$ salts to obtain a pure culture. The $16 \mathrm{~S}$ rRNA gene sequence of the isolate was amplified by Colony PCR with PCR Pre-Mix (SolGent) and two bacteria-specific primers (8F, 1492R) (Baker et al., 2003). After purification (QIAquick PCR Purification kit), the PCR product was sequenced using a BigDye Terminator Cycle Sequencing Ready Reaction kit (Applied Biosystems) according to the manufacturer's instructions. The reaction mixtures were analysed by using an automated DNA analyser system (PRISM 3730XL DNA analyzer; Applied Biosystems). The $16 \mathrm{~S}$ rRNA gene sequence of the isolate was then compared with other sequences in the GenBank (NCBI) database. As a result, the isolate was identified as a member of the genus Cobetia in the 
Gammaproteobacteria; its 16S rRNA gene sequence shared $98.9 \%$ similarity with that of C. marina DSM $4741^{\mathrm{T}}$. Moreover, 16S rRNA gene sequence similarities between the isolate and members of the genus Halomonas were less than $95.0 \%$. Three primers ( $8 \mathrm{~F}, 1088 \mathrm{R}$ and $1492 \mathrm{R})$ were introduced to obtain a nearly complete $16 \mathrm{~S}$ rRNA gene sequence of the isolate. The 16S rRNA gene sequences were subsequently assembled by SEQMAN software (DNASTAR) and aligned using the multiple sequence alignment program CLUSTAL_X (1.83) (Thompson et al., 1997). The trimmed alignment was converted to MEGA and PHYLIP formats for phylogenetic analyses. The relationships between strain $\mathrm{JO}^{\mathrm{T}}$ and strains of other closely related species were shown using phylogenetic consensus trees based on neighbour-joining and maximum-parsimony methods constructed using MEGA 4 (Tamura et al., 2007) and a phylogenetic consensus tree based on the maximum-likelihood method constructed using PHYLIP (Felsenstein, 2004); relationships were assessed by randomly selecting 1000, 1000 and 300 bootstrap replicates for the neighbour-joining, maximum-parsimony and maximum-likelihood algorithms, respectively (Felsenstein, 1981; Kluge \& Farris, 1969; Saitou \& Nei, 1987). Phylogenetic consensus trees were visualized with MEGA 4 (Tamura et al., 2007). Phylogenetic analysis indicated that strain $\mathrm{JO}^{\mathrm{T}}$ was closely related to Cobetia marina in the family Halomonadaceae (Fig. 1).

To determine optimal culture conditions of strain $\mathrm{JO1}^{\mathrm{T}}$, growth of the isolate was tested under various conditions. Growth was determined in marine broth $(\mathrm{MB}$; $\mathrm{BBL}$ ) containing various concentrations of $\mathrm{NaCl}(0,0.5,1,2,3$, $5,7.5,10,15,20,25$ and $30 \%$, w/v) for 48 h. Growth was assessed at various temperatures $(0,4,10,15,25,30,37,40$ and $\left.43{ }^{\circ} \mathrm{C}\right)$ for $96 \mathrm{~h}$ and at different $\mathrm{pH}(4,5,6,7,8,9$ and 10) for $48 \mathrm{~h}$ in $\mathrm{MB}$ supplemented with $6.5 \%$ salts. Growth of the isolate occurred under a range of conditions:

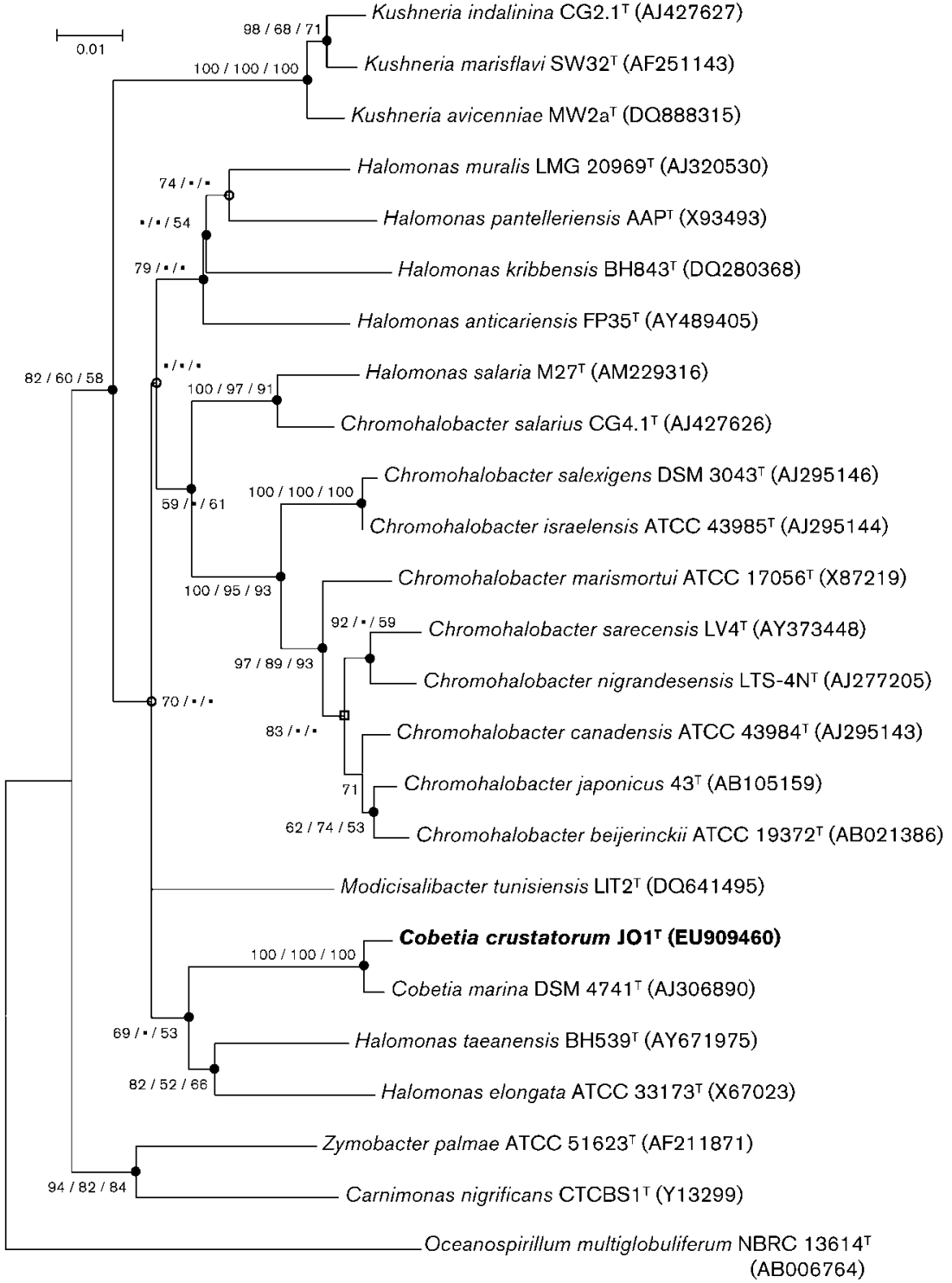

Fig. 1. Phylogenetic consensus tree based on $16 \mathrm{~S}$ rRNA gene sequences. Filled circles, generic branches that are present in phylogenetic consensus trees generated by using the neighbour-joining, maximum-parsimony and maximum-likelihood algorithms; open circles, generic branches that are present in trees generated by using the neighbour-joining and maximum-parsimony algorithms; open squares, generic branches that are present in trees generated by using the neighbour-joining and maximum-likelihood algorithms. Numbers at nodes indicate bootstrap values as percentages of 1000,1000 and 300 replicates, respectively (neighbour-joining probability/ maximum-parsimony probability/maximum-likelihood probability). Values lower than $50 \%$ are not indicated at the branch points. Bar, 1 substitution per $100 \mathrm{nt}$ positions. 
$3.5-11.5 \%$ salts, $4-30{ }^{\circ} \mathrm{C}$ and $\mathrm{pH} 5-10$. Growth was best on $6.5 \%(\mathrm{w} / \mathrm{v})$ salts at $25^{\circ} \mathrm{C}$ and $\mathrm{pH} 5.0-6.0$. All tests used to characterize the isolate were performed at $25{ }^{\circ} \mathrm{C}$ and $\mathrm{pH} 7.5 \pm 0.2$ on MA containing $6.5 \%$ salts unless stated otherwise. Gram-staining was accomplished using the method of Gram (1884). Poly- $\beta$-hydroxybutyric acid (PHB) was examined by using the Sudan Black B method (Smibert \& Krieg, 1994). Production of exopolysaccharide was examined after cultivation on MH medium (Quesada et al., 1983) for 5 days. Both light microscopy (ECLIPSE $80 i$; Nikon) and transmission electron microscopy (JEM 1010; JEOL) were used to determine cell shape, size, colour, flagella, PHB staining and Gram-staining. Respiration on fumarate, nitrate and nitrite was studied according to Callies \& Mannheim (1978) with $\mathrm{MH}$ medium at $30{ }^{\circ} \mathrm{C}$ for 7 days in an anaerobic chamber maintained in an atmosphere of $\mathrm{N}_{2}: \mathrm{CO}_{2}: \mathrm{H}_{2}(8: 1: 1)$. Catalase and oxidase activities were investigated with a $3 \%(\mathrm{v} / \mathrm{v})$ hydrogen peroxide solution and $1 \%(\mathrm{w} / \mathrm{v})$ p-tetramethyl phenylenediamine (bioMérieux), respectively. DNA degradation was assessed on DNase agar (BBL). Hydrolysis of L-tyrosine was tested by incubating the isolate on optimal medium supplemented with L-tyrosine, after each component was autoclaved separately (Gordon et al., 1974). For the Tweens (80 and 20) decomposition test, the optimal growth medium was supplemented with $0.01 \%(\mathrm{w} / \mathrm{v}) \mathrm{CaCl}_{2}$ and $1 \%(\mathrm{v} / \mathrm{v})$ Tween (80 or 20) (Holding \& Collee, 1971). Hydrolysis of starch and casein were tested by incubating the isolate on optimal medium supplemented with $0.5 \%$ $(\mathrm{w} / \mathrm{v})$ soluble starch (BBL) or skim milk agar, respectively. Skim milk agar was prepared by mixing $5 \%(\mathrm{w} / \mathrm{v})$ skim milk (BBL) with $2 \%$ agar and $5 \% \mathrm{NaCl}$ in distilled water, after each component had been individually autoclaved and cooled to $45^{\circ} \mathrm{C}$. Citrate utilization was tested on Simmons citrate agar (BBL). Phenylalanine agar (BBL) was used to test phenylalanine deaminase activity. Hydrogen sulfide production from L-cysteine was tested with Kligler iron agar (BBL). Methyl red and Voges-Proskauer reactions were performed using MR-VP medium (BBL). $\beta$ Galactosidase (ONPG test), indole production, urease activity, lysine decarboxylase, ornithine decarboxylase, reduction of nitrate to nitrite under aerobic conditions and oxidation/fermentation of D-glucose were assessed by using API 20E and 20NE strips (bioMérieux). API ZYM (bioMérieux) was used to assess other enzyme activities. Oxidative metabolism of carbohydrates by strain $\mathrm{JO}^{\mathrm{T}}$ on the basis of acid reaction was tested using oxidation/ fermentation (OF) basal medium (BBL). Carbohydrates in API $50 \mathrm{CH}$ (bioMérieux) tubes were provided for use in OF basal medium. Utilization of substrates as sole carbon or nitrogen sources was also demonstrated as recommended by Arahal et al. (2007) and Mata et al. (2002) by introducing API $50 \mathrm{CH}$ strips and Biolog GN2 MicroPlates according to the manufacturers' instructions. All suspension media were added to $5 \% \mathrm{NaCl}$ and all strips were incubated at $25{ }^{\circ} \mathrm{C}$. Susceptibility of the isolate to antibiotics was defined by the disc diffusion method. The following discs were used: ampicillin $(10 \mu \mathrm{g})$, kanamycin
(30 $\mu \mathrm{g})$, chloramphenicol $(30 \mu \mathrm{g})$, erythromycin $(15 \mu \mathrm{g})$, streptomycin $(10 \mu \mathrm{g})$ and polymyxin B (300 IU) (Mata et al., 2002). The results of phenotypic characterization are given in Table 1 and the species description.

Fatty acids of strain $\mathrm{JO}^{\mathrm{T}}$ and C. marina DSM $4741^{\mathrm{T}}$ were extracted as described by the Sherlock Microbial Identification System (MIDI, 1999) from cells grown together for $72 \mathrm{~h}$ on $\mathrm{MA}$ with $2 \% \mathrm{NaCl}$ at $30{ }^{\circ} \mathrm{C}$ and $\mathrm{pH}$ 7.6. Fatty acids were analysed by GC (Hewlett Packard 6890) and identified with the Microbial Identification software package (Sasser, 1990). The cellular fatty acid compositions of these strains are presented in Table 2. The genomic DNA of strain $\mathrm{JO}^{\mathrm{T}}$ and C. marina DSM $4741^{\mathrm{T}}$ were assessed for DNA-DNA hybridization and $\mathrm{G}+\mathrm{C}$ content following extraction by using a G-spin Genomic DNA extraction kit (iNtRON Biotechnology). Preliminary comparison of the $16 \mathrm{~S}$ rRNA gene sequence of strain $\mathrm{JO}^{\mathrm{T}}$ with those of references in GenBank showed that the isolate had $98.9 \%$ similarity with C. marina DSM $4741^{\mathrm{T}}$ in the family Halomonadaceae. It is recommended that a DNADNA reassociation value of about $70 \%$ plays a dominant role in classification at the species level (Stackebrandt \& Goebel, 1994; Wayne et al., 1987). To verify the extent of genetic relatedness, DNA-DNA hybridization experiments (Ezaki et al., 1989) were performed according to a modified method of Hirayama et al. (1996); specifically, probe DNA was labelled by boiling at $100{ }^{\circ} \mathrm{C}$ for $30 \mathrm{~min}$ with photobiotin instead of illuminating the probe under a $400 \mathrm{~W}$ mercury vapour lamp. Reportedly, bacterial strains with $16 \mathrm{~S}$ rRNA gene sequence similarities greater than $97 \%$ do not belong to the same species unless the extent of DNA-DNA hybridization is greater than $70 \%$ (Stackebrandt \& Goebel, 1994; Wayne et al., 1987). DNA-DNA hybridization between strains $\mathrm{JO}^{\mathrm{T}}$ and $C$. marina DSM $4741^{\mathrm{T}}$ was $24 \%$. To predict the DNA G $+\mathrm{C}$ content of strain $\mathrm{JO}^{\mathrm{T}}$, a fluorimetric method employing SYBR Green I and real-time PCR was carried out (Gonzalez \& Saiz-Jimenez, 2002). Genomic DNAs from Escherichia coli K-12 and C. marina DSM $4741^{\mathrm{T}}$ were used as the calibration references (Gonzalez \& Saiz-Jimenez, 2002). The DNA G $+C$ content of the isolate was estimated as $61.4 \mathrm{~mol} \%$. Not only is this value within the $52-$ $68 \mathrm{~mol} \%$ range of the genus Halomonas, but is comparable with the DNA $\mathrm{G}+\mathrm{C}$ content of $C$. marina.

Based on phenotypic, genotypic and phylogenetic analyses, it is proposed that strain $\mathrm{JO}^{\mathrm{T}}$ represents a novel species belonging to the genus Cobetia.

\section{Description of Cobetia crustatorum sp. nov.}

Cobetia crustatorum (cru.sta.to' rum. N.L. part. n. crustatus crustated; N.L. gen. pl. n. crustatorum of shellfish).

Aerobic, Gram-stain-negative and slightly halophilic micro-organism. Cells are rod-shaped, $0.6-1.5 \mu \mathrm{m}$ in length, $0.6 \mu \mathrm{m}$ in width, and generally observed as single cells or pairs. Cells have $2-5$ peritrichous flagella. Colonies are less than $3 \mathrm{~mm}$ in diameter, round, glistening, raised 
Table 1. Differential features of strain $\mathrm{JO}^{\top}{ }^{\top}$ (C. crustatorum sp. nov.) and C. marina DSM $4741^{\top}$

Data are from this study, except where indicated. Both strains were positive for catalase activity and hydrolysis of tyrosine and DNA. Both strains were negative for Gram staining, oxidase activity, nitrate reduction to nitrite, indole production, urease, lysine and ornithine decarboxylases, hydrolysis of casein, starch, gelatin, aesculin and Tweens (80 and 20), phenylalanine deaminase, methyl red and Voges-Proskauer tests, $\mathrm{H}_{2} \mathrm{~S}$ production, and respiration on fumarate, nitrate and nitrite. They both metabolized glycerol, D-galactose, D-glucose, D-fructose, D-mannose and trehalose in API $50 \mathrm{CH}$ tests and D-fructose, D-galactose, $\alpha$-D-glucose, $\alpha$-ketoglutaric acid, bromosuccinic acid, L-asparagine and L-glutamic acid in the Biolog system.

\begin{tabular}{|c|c|c|}
\hline Characteristic & Strain $\mathrm{JO1}^{\mathrm{T}}$ & C. marina DSM $4741^{\mathrm{T}}$ \\
\hline Optimal temperature $\left({ }^{\circ} \mathrm{C}\right)^{*}$ & 25 & 37 \\
\hline Motility* & + & - \\
\hline$\beta$-Galactosidase (ONPG) & + & - \\
\hline D-Glucose fermentation & - & + \\
\hline \multicolumn{3}{|l|}{ Acid production from: } \\
\hline Glycerol & + & - \\
\hline D-Xylose & + & - \\
\hline D-Fructose & + & - \\
\hline D-Lactose & - & + \\
\hline 5-Ketogluconate & - & + \\
\hline Amygdalin & - & + \\
\hline Salicin & - & + \\
\hline Cellobiose & - & + \\
\hline Maltose & + & - \\
\hline Sucrose & + & - \\
\hline Melezitose & - & + \\
\hline Starch & - & + \\
\hline Turanose & - & + \\
\hline D-Arabitol & - & + \\
\hline Gluconate & - & + \\
\hline \multicolumn{3}{|l|}{ Biolog system } \\
\hline Glycogen & - & + \\
\hline Turanose & + & - \\
\hline Pyruvic acid methyl ester & + & - \\
\hline cis-Aconitic acid & + & - \\
\hline Citric acid & + & - \\
\hline D-Gluconic acid & + & - \\
\hline$\beta$-Hydroxybutyric acid & - & + \\
\hline$\gamma$-Hydroxybutyric acid & + & - \\
\hline$p$-Hydroxybutyric acid & + & - \\
\hline DL-Lactic acid & + & - \\
\hline Succinamic acid & - & + \\
\hline L-Alanine & + & - \\
\hline L-Alanyl glycine & + & - \\
\hline L-Aspartic acid & - & + \\
\hline Glycyl L-aspartic acid & - & + \\
\hline
\end{tabular}


Table 1. cont.

\begin{tabular}{|lcc|}
\hline Characteristic & Strain JO1 $^{\text {T }}$ & ${\text { C. } \text { marina }^{\text {DSM }} \text { 4741 }}^{\text {T }}$ \\
\hline Glycyl L-glutamic acid & + & - \\
L-Proline & + & - \\
L-Pyroglutamic acid & + & - \\
L-Serine & + & - \\
$\gamma$-Aminobutyric acid & - & - \\
Inosine & + & + \\
Glycerol & + & - \\
DL- $\alpha$-Glycerol phosphate & 61.4 & - \\
DNA G + C content (mol\%) & Salt-fermented food & 62.4 \\
Isolation source & & Coastal sea sample \\
\end{tabular}

*Data are from Arahal et al. (2002a), Mata et al. (2002) and the present study.

and cream-coloured. Grows under a range of conditions: 4-30 ${ }^{\circ} \mathrm{C}$; 3.5-11.5\% salts; and $\mathrm{pH}$ 5.0-10.0. Optimal growth occurs at $25{ }^{\circ} \mathrm{C}$, at $\mathrm{pH} 5.0-6.0$ and in $6.5 \%$ salts. Cells produce exopolysaccharide and accumulate PHB. Oxidase-negative and catalase-positive. Hydrolyses L-tyrosine, DNA and ONPG, but not casein, starch, gelatin, urea or Tweens (80 and 20). Oxidative metabolism occurs from D-glucose; indole is not produced. Lysine and ornithine decarboxylases are not produced. The Simmons citrate, methyl red and Voges-Proskauer tests, phenylalanine deaminase, and hydrogen sulfide production from Lcysteine are negative. Respiration on fumarate, nitrate and nitrite is negative. Reduction of nitrate to nitrite under

Table 2. Cellular fatty acid contents (\%) of strain $\mathrm{JO} 1^{\top}$ (C. crustatorum sp. nov.) and C. marina DSM $4741^{\top}$

All data shown are from the present study and were determined under the same conditions. Values shown are percentages of total fatty acids. tr, Trace (less than $1.0 \%$ ); - , not detected.

\begin{tabular}{|lcc|}
\hline Fatty acid & Strain JO1 $^{\mathrm{T}}$ & $\begin{array}{c}\text { C. } \text { marina } \text { DSM } \\
\mathbf{4 7 4 1}^{\mathbf{T}}\end{array}$ \\
\hline $\mathrm{C}_{10: 0}$ & 4.5 & 1.7 \\
$\mathrm{C}_{12: 0}$ & 8.0 & 4.0 \\
$\mathrm{C}_{12: 0} 3-\mathrm{OH}$ & 25.3 & 9.5 \\
$\mathrm{C}_{14: 0}$ & 1.2 & $\operatorname{tr}$ \\
$\mathrm{C}_{16: 0}$ & 24.6 & 26.0 \\
$\mathrm{C}_{16: 0} 3-\mathrm{OH}$ & - & $\operatorname{tr}$ \\
$\mathrm{C}_{17: 0}$ & - & $\operatorname{tr}$ \\
$\mathrm{C}_{17: 0}$ cyclo & 9.4 & 13.8 \\
$\mathrm{C}_{18: 0}$ & 1.0 & $\operatorname{tr}$ \\
$\mathrm{C}_{18: 1} \omega 7 c$ & 3.8 & 20.7 \\
$\mathrm{C}_{19: 0}$ cyclo $\omega 8 c$ & - & 4.9 \\
10 -methyl $\mathrm{C}_{19: 0}$ & - & $\operatorname{tr}$ \\
Summed feature $3 *$ & 22.2 & 16.7 \\
\hline
\end{tabular}

${ }^{\star}$ Summed feature 3 comprises $\mathrm{C}_{16: 1} \omega 7 \mathrm{c} /$ iso- $\mathrm{C}_{15: 0} 2-\mathrm{OH}$. aerobic conditions is negative. Acid is produced from glycerol, D-xylose, D-galactose, D-glucose, D-fructose, Dmannose, cellobiose, maltose and $\mathrm{D}$-fucose, but not from erythritol, D-arabinose, L-arabinose, D-ribose, L-xylose, Dadonitol, methyl $\beta$-D-xyloside, L-sorbose, L-rhamnose, dulcitol, inositol, D-mannitol, D-sorbitol, methyl $\alpha$-Dmannoside, methyl $\alpha$-D-glucoside, $N$-acetylglucosamine, amygdalin, arbutin, aesculin, salicin, D-lactose, melibiose, sucrose, trehalose, inulin, melezitose, raffinose, starch, glycogen, xylitol, gentiobiose, turanose, D-lyxose, D-tagatose, L-fucose, D-arabitol, L-arabitol, gluconate, 2-ketogluconate or 5-ketogluconate. Utilizes glycerol, D-galactose, Dglucose, D-fructose, D-mannose, maltose, sucrose and trehalose in API $50 \mathrm{CH}$ strips, but not erythritol, Darabinose, L-arabinose, D-ribose, D-xylose, L-xylose, Dadonitol, methyl $\beta$-D-xyloside, L-sorbose, L-rhamnose, dulcitol, inositol, D-mannitol, D-sorbitol, methyl $\alpha$-Dmannoside, methyl $\alpha$-D-glucoside, $N$-acetylglucosamine, amygdalin, arbutin, aesculin, salicin, cellobiose, D-lactose, melibiose, inulin, melezitose, raffinose, starch, glycogen, xylitol, gentiobiose, turanose, D-lyxose, D-tagatose, Dfucose, L-fucose, D-arabitol, L-arabitol, gluconate, 2-ketogluconate or 5-ketogluconate. In Biolog GN2 MicroPlates, metabolizes L-arabinose, D-fructose, D-galactose, $\alpha$-D-glucose, maltose, D-mannitol, sucrose, turanose, glycerol, Dgluconic acid, lactulose, D-psicose, Tween 80, pyruvic acid methyl ester, cis-aconitic acid, citric acid, $\gamma$-hydroxybutyric acid, $p$-hydroxyphenylacetic acid, $\alpha$-ketoglutaric acid, DLlactic acid, bromosuccinic acid, L-alanine, L-alanyl glycine, L-asparagine, L-glutamic acid, glycyl L-glutamic acid, Lproline, L-pyroglutamic acid, L-serine, $\gamma$-aminobutyric acid and $\alpha$-D-glucose 1 -phosphate, but not glycogen, $N$-acetylD-glucosamine, adonitol, D-arabitol, cellobiose, $i$-erythritol, L-fucose, gentiobiose, myo-inositol, D-lactose, D-mannose, melibiose, raffinose, L-rhamnose, D-sorbitol, trehalose, xylitol, D-arabinose, dulcitol, methyl $\alpha$-D-mannoside, methyl $\alpha$-D-glucoside, amygdalin, arbutin, aesculin, salicin, inulin, melezitose, starch, D-tagatose, L-arabitol, 2-ketogluconate, 5 -ketogluconate, methyl $\beta$-D-glucoside, $\alpha$-cyclodextrin, dextrin, Tween $40, N$-acetyl-D-galactosamine, succinic 
acid monomethyl ester, acetic acid, formic acid, Dgalactonic acid lactone, D-galacturonic acid, D-glucosaminic acid, D-glucuronic acid, $\alpha$-hydroxybutyric acid, $\beta$ hydroxybutyric acid, itaconic acid, $\alpha$-ketobutyric acid, $\alpha$ ketovaleric acid, malonic acid, propionic acid, quinic acid, D-saccharic acid, sebacic acid, succinic acid, succinamic acid, glucuronamide, L-alaninamide, D-alanine, L-aspartic acid, glycyl L-aspartic acid, L-histidine, hydroxy-L-proline, L-leucine, L-ornithine, L-phenylalanine, D-serine, L-threonine, DL-carnitine, urocanic acid, inosine, uridine, thymidine, phenylethylamine, putrescine, 2-aminoethanol, 2,3butanediol, DL- $\alpha$-glycerol phosphate or D-glucose 6-phosphate. Positive for alkaline phosphatase, esterase (C4), esterase lipase (C8), leucine arylamidase, cystine arylamidase, trypsin, acid phosphatase, naphthol-AS-BI-phosphohydrolase and $\beta$-galactosidase, but negative for lipase (C14), valine arylamidase, $\alpha$-chymotrypsin, $\alpha$-galactosidase, $\beta$-glucuronidase, $\alpha$-glucosidase, $\beta$-glucosidase, $N$-acetyl- $\beta$ glucosaminidase, $\alpha$-mannosidase and $\alpha$-fucosidase. Susceptible to ampicillin $(10 \mu \mathrm{g})$, kanamycin $(30 \mu \mathrm{g})$, chloramphenicol $(30 \mu \mathrm{g})$, erythromycin $(15 \mu \mathrm{g})$, streptomycin $(10 \mu \mathrm{g})$ and polymyxin B (300 IU). Major fatty acids are $\mathrm{C}_{12: 0} 3-\mathrm{OH}, \mathrm{C}_{16: 0}, \mathrm{C}_{17: 0}$ cyclo and summed feature $3\left(\mathrm{C}_{16: 1} \omega 7 c /\right.$ iso- $\left.\mathrm{C}_{15: 0} 2-\mathrm{OH}\right)$.

The type strain is $\mathrm{JO}^{\mathrm{T}}\left(=\mathrm{KCTC} 22486^{\mathrm{T}}=\mathrm{JCM} 15644^{\mathrm{T}}\right)$, isolated from 'Jogae jeotgal', a type of traditional Korean fermented seafood. The DNA G+C content of the type strain is $61.4 \mathrm{~mol} \%$.

\section{Acknowledgements}

We thank Professor J. P. Euzéby (Ecole Nationale Vétérinaire, France) for etymological advice. This work was supported by the Environmental Biotechnology National Core Research Center (KOSEF: R15-2003-012-02002-0) and TDPAF (Technology Development Program for Agriculture and Forestry) of the Ministry for Agriculture, Forestry and Fisheries.

\section{References}

Arahal, D. R., Castillo, A. M., Ludwig, W., Schleifer, K. H. \& Ventosa, A. (2002a). Proposal of Cobetia marina gen. nov., comb. nov., within the family Halomonadaceae, to include the species Halomonas marina. Syst Appl Microbiol 25, 207-211.

Arahal, D. R., Ludwig, W., Schleifer, K. H. \& Ventosa, A. (2002b). Phylogeny of the family Halomonadaceae based on 23S and 16S rDNA sequence analyses. Int J Syst Evol Microbiol 52, 241-249.

Arahal, D. R., Vreeland, R. H., Litchfield, C. D., Mormile, M. R., Tindall, B. J., Oren, A., Bejar, V., Quesada, E. \& Ventosa, A. (2007). Recommended minimal standards for describing new taxa of the family Halomonadaceae. Int J Syst Evol Microbiol 57, 2436-2446.

Baker, G. C., Smith, J. J. \& Cowan, D. A. (2003). Review and re-analysis of domain-specific $16 \mathrm{~S}$ primers. J Microbiol Methods 55, 541-555.

Baumann, L., Baumann, P., Mandel, M. \& Allen, R. D. (1972). Taxonomy of aerobic marine eubacteria. J Bacteriol 110, 402-429.

Baumann, L., Bowditch, R. D. \& Baumann, P. (1983). Description of Deleya gen. nov. created to accommodate the marine species Alcaligenes aestus, A. pacificus, A. cupidus, A. venustus, and Pseudomonas marina. Int J Syst Bacteriol 33, 793-802.
Callies, E. \& Mannheim, W. (1978). Classification of the Flavobacterium-Cytophaga complex on the basis of respiratory quinones and fumarate respiration. Int J Syst Bacteriol 28, 14-19.

Cobet, A. B., Wirsen, C., Jr \& Jones, G. E. (1970). The effect of nickel on a marine bacterium, Arthrobacter marinus sp. nov. J Gen Microbiol 62, 159-169.

Dobson, S. J. \& Franzmann, P. D. (1996). Unification of the genera Deleya (Baumann et al. 1983), Halomonas (Vreeland et al. 1980), and Halovibrio (Fendrich 1988) and the species Paracoccus halodenitrificans (Robinson and Gibbons 1952) into a single genus, Halomonas, and placement of the genus Zymobacter in the family Halomonadaceae. Int J Syst Bacteriol 46, 550-558.

Ezaki, T., Hashimoto, Y. \& Yabuuchi, E. (1989). Fluorometric deoxyribonucleic acid-deoxyribonucleic acid hybridization in microdilution wells as an alternative to membrane filter hybridization in which radioisotopes are used to determine genetic relatedness among bacterial strains. Int J Syst Bacteriol 39, 224-229.

Felsenstein, J. (1981). Evolutionary trees from DNA sequences: a maximum likelihood approach. J Mol Evol 17, 368-376.

Felsenstein, J. (2004). PHYLIP (phylogeny inference package), version 3.6. Distributed by the author. Department of Genome Sciences, University of Washington, Seattle, USA.

Gonzalez, J. M. \& Saiz-Jimenez, C. (2002). A fluorimetric method for the estimation of $\mathrm{G}+\mathrm{C}$ mol\% content in microorganisms by thermal denaturation temperature. Environ Microbiol 4, 770-773.

Gordon, R. E., Barnett, D. A., Handerhan, J. E. \& Pang, C. H.-N. (1974). Nocardia coeliaca, Nocardia autotrophica, and the nocardin strain. Int J Syst Bacteriol 24, 54-63.

Gram, H. (1884). Über die isolierte Färbung der Schizomyceten in Schnitt- und Trockenpräparaten. Fortschr Med 2, 185-189 (in German).

Hirayama, H., Tamaoka, J. \& Horikoshi, K. (1996). Improved immobilization of DNA to microwell plates for DNA-DNA hybridization. Nucleic Acids Res 24, 4098-4099.

Holding, A. J. \& Collee, J. G. (1971). Routine biochemical tests. Methods Microbiol 6A, 1-32.

Kluge, A. G. \& Farris, J. S. (1969). Quantitative phyletics and the evolution of anurans. Syst Zool 18, 1-32.

Mata, J. A., Martínez-Cánovas, J., Quesada, E. \& Béjar, V. (2002). A detailed phenotypic characterisation of the type strains of Halomonas species. Syst Appl Microbiol 25, 360-375.

MIDI (1999). Sherlock Microbial Identification System Operating Manual, version 3.0. Newark, DE: MIDI Inc.

Quesada, E., Ventosa, A., Rodriguez-Valera, F., Megias, L. \& RamosCormenzana, A. (1983). Numerical taxonomy of moderately halophilic Gram-negative bacteria from hypersaline soils. J Gen Microbiol 129, 2649-2657.

Romanenko, L. A., Schumann, P., Rohde, M., Mikhailov, V. V. \& Stackebrandt, E. (2002). Halomonas halocynthiae sp. nov., isolated from the marine ascidian Halocynthia aurantium. Int J Syst Evol Microbiol 52, 1767-1772.

Saitou, N. \& Nei, M. (1987). The neighbor-joining method: a new method for reconstructing phylogenetic trees. Mol Biol Evol 4, 406425.

Sasser, M. (1990). Identification of bacteria by gas chromatography of cellular fatty acids. USFCC Newsl 20, 16.

Smibert, R. M. \& Krieg, N. R. (1994). Phenotypic characterization. In Methods for General and Molecular Bacteriology, pp. 607-654. Edited by P. Gerhardt, R. G. E. Murray, W. A. Wood \& N. R. Krieg. Washington, DC: American Society for Microbiology. 
Stackebrandt, E. \& Goebel, B. M. (1994). Taxonomic note: a place for DNA-DNA reassociation and $16 \mathrm{~S}$ rRNA sequence analysis in the present species definition in bacteriology. Int J Syst Bacteriol 44, 846849.

Suh, H. K. \& Yoon, S. S. (1987). A study on the regional characteristics of Korean chotkal. Korean J Diet Cult 2, 45-54.

Tamura, K., Dudley, J., Nei, M. \& Kumar, S. (2007). MEGA4: molecular evolutionary genetics analysis (MEGA) software version 4.0. Mol Biol Evol 24, 1596-1599.
Thompson, J. D., Gibson, T. J., Plewniak, F., Jeanmougin, F. \& Higgins, D. G. (1997). The CLUSTAL_X windows interface: flexible strategies for multiple sequence alignment aided by quality analysis tools. Nucleic Acids Res 25, 4876-4882.

Wayne, L. G., Brenner, D. J., Colwell, R. R., Grimont, P. A. D., Kandler, O., Krichevsky, M. I., Moore, L. H., Moore, W. E. C., Murray, R. G. E. \& other authors (1987). International Committee on Systematic Bacteriology. Report of the ad hoc committee on reconciliation of approaches to bacterial systematics. Int J Syst Bacteriol 37, 463-464. 